\title{
Mapping of single-copy genes by TSA-FISH in the codling moth, Cydia pomonella
}

Leonela Z Carabajal Paladino $^{1 \dagger}$, Petr Nguyen ${ }^{1,2+}$, Jindra Šíchová ${ }^{1,2}$, František Marec ${ }^{1,2^{*}}$

\begin{abstract}
Background: We work on the development of transgenic sexing strains in the codling moth, Cydia pomonella (Tortricidae), which would enable to produce male-only progeny for the population control of this pest using sterile insect technique (SIT). To facilitate this research, we have developed a number of cytogenetic and molecular tools, including a physical map of the codling moth Z chromosome using BAC-FISH (fluorescence in situ hybridization with bacterial artificial chromosome probes). However, chromosomal localization of unique, singlecopy sequences such as a transgene cassette by conventional FISH remains challenging. In this study, we adapted a FISH protocol with tyramide signal amplification (TSA-FISH) for detection of single-copy genes in Lepidoptera. We tested the protocol with probes prepared from partial sequences of Z-linked genes in the codling moth.

Results: Using a modified TSA-FISH protocol we successfully mapped a partial sequence of the Acetylcholinesterase 1 (Ace-1) gene to the Z chromosome and confirmed thus its Z-linkage. A subsequent combination of BAC-FISH with BAC probes containing anticipated neighbouring Z-linked genes and TSA-FISH with the Ace-1 probe allowed the integration of Ace-1 in the physical map of the codling moth Z chromosome. We also developed a two-colour TSA-FISH protocol which enabled us simultaneous localization of two Z-linked genes, Ace-1 and Notch, to the expected regions of the $Z$ chromosome.

Conclusions: We showed that TSA-FISH represents a reliable technique for physical mapping of genes on chromosomes of moths and butterflies. Our results suggest that this technique can be combined with BAC-FISH and in the future used for physical localization of transgene cassettes on chromosomes of transgenic lines in the codling moth or other lepidopteran species. Furthermore, the developed protocol for two-colour TSA-FISH might become a powerful tool for synteny mapping in non-model organisms.
\end{abstract}

\section{Background}

Codling moth, Cydia pomonella (Linnaeus), has one of the worst reputation of all representatives of the microlepidopteran family Tortricidae, for it is virtually cosmopolitan pest that causes severe crop damage in pome fruit and walnut orchards [1-3]. The codling moth control has been mainly achieved by intensive use of broad spectrum chemical insecticides. However, their use led to the development of resistance and cross-resistance to many registered pesticides of various chemical classes [4-6]. Moreover, insecticide-induced disruption of natural control, i.e. elimination of non-target predator

\footnotetext{
* Correspondence: marec@entu.cas.cz

† Contributed equally

'Institute of Entomology, Biology Centre ASCR, Branišovská 31, 37005 České Budějovice, Czech Republic

Full list of author information is available at the end of the article
}

populations, may result in outbreaks of secondary pests such as aphids and phytophagous mites $[7,8]$. There are also concerns over environmental contamination and effect of insecticides on human health. These issues along with growing environmental awareness of the general public increase calls for efficient and sustainable pest control methods [9].

One such environment-friendly control method is the sterile insect technique (SIT), the effectiveness of which has been demonstrated in many insect pests [10]. The SIT has been successfully implemented as a part of areawide integrated pest-management programmes for suppressing codling moth populations in British Columbia, Canada [11]. Since 1992, mass-reared moths have been sterilized by gamma radiation and released in the Okanagan region of British Columbia [12,13]. The sterile males mate with wild females but produce no offspring due to
C Biomed Central

ㄷ 2014 Carabajal Paladino et al.; licensee BioMed Central Ltd. This is an Open Access article distributed under the terms of the Creative Commons Attribution License (http://creativecommons.org/licenses/by/3.0), which permits unrestricted use, distribution, and reproduction in any medium, provided the original work is properly cited. 
the radiation-induced dominant lethal mutations transferred by sperm [14]. Elimination of codling moth infestation along with a drop in the use of insecticides in most treated orchards of British Columbia has increased interest in the expansion of codling moth SIT to other countries [15]. The codling moth SIT relies on bisexual releases, but there are reasons to believe that male-only releases would bring significant improvement to this technology as it has been demonstrated in the medfly, Ceratitis capitata, where the release of irradiated males only is severalfold more efficient in inducing sterility in wild insect populations than the release of both sexes [16-19]. However, an efficient technology of sex separation that would be easily applicable under mass rearing conditions has not yet been developed in C. pomonella. Therefore, a new approach for genetic sexing in the codling moth has been proposed. It is based on the development of a transgenic C. pomonella strain with females carrying a dominant conditional lethal mutation (DCLM) in the female-specific W chromosome. Under restrictive conditions all female progeny would be eliminated due to the presence of the $\mathrm{W}$ chromosome bearing the DCLM transgene, whereas non-transgenic males would survive and could be irradiated and released upon emergence [20]. A dominant cold sensitive mutant allele of the Notch gene, originally isolated in Drosophila melanogaster, has been chosen as a suitable DCLM [21], and the codling moth transgenesis is currently under way [22].

To facilitate the development of genetic sexing strains, the codling moth genome organization has been extensively studied with emphasis on its sex chromosomes and their molecular differentiation. It was shown that the karyotype of $C$. pomonella consists of $2 n=56$ holokinetic chromosomes, i.e. chromosomes lacking localized centromere [23], which seems to represent the modal chromosome number in the tortricid subfamily Olethreutinae [24] to which the codling moth belongs. The largest chromosome pair corresponding to the $\mathrm{W}$ and $\mathrm{Z}$ sex chromosomes in females was further probed by means of genomic in situ hybridization, comparative genomic hybridization, and W-specific painting probes. The codling moth W chromosome was shown to be highly differentiated from the $\mathrm{Z}$ chromosome at the molecular level and composed predominantly of repetitive sequences $[23,25]$. W-derived female specific molecular markers were also developed and successfully used to identify the sex in the early developmental stages of the codling moth [22]. Furthermore, comparative physical mapping of the $\mathrm{Z}$ sex chromosome was performed in the codling moth using fluorescence in situ hybridization (FISH) with probes derived from bacterial artificial chromosome (BAC) clones. The mapping of genes using BAC-FISH revealed that the $\mathrm{Z}$ chromosome of this species arose by a fusion between an ancestral $\mathrm{Z}$ sex chromosome and an autosome corresponding to chromosome 15 in the silkworm (Bombyx mori) reference genome. Interestingly, the silkworm chromosome 15 harbours the $A B C$ transporter $C 2(A B C C 2)$ and Acetylcholinesterase 1 (Ace-1) genes, which confer resistance to Bacillus thuringiensis toxin Cry1 Ab and insensitivity to organophosphate and carbamate insecticides, respectively. In addition, the Notch gene, whose mutant form is proposed for germ-line transformation of the codling moth, is also located on chromosome 15 in the silkworm. While $A B C C 2$ and Notch were mapped directly to the codling moth $\mathrm{Z}$ chromosome by BAC-FISH, no BAC clone was available in case of Ace-1, and its sexlinkage was inferred from a comparison of male and female gene dose by quantitative PCR (qPCR) [26].

Both physical map of the codling moth $\mathrm{Z}$ chromosome and W-derived female specific molecular markers can be used for physical mapping of transgenes in genetic sexing strains once available. However, chromosomal localization of unique, single-copy sequences such as a transgene cassette remains challenging, since threshold for routine detection by conventional FISH protocols ranges between 5 to $10 \mathrm{kbp}[27,28]$. In this study, we adapted a FISH protocol involving enzyme mediated deposition of fluorophore-labelled tyramide, the so-called tyramide signal amplification (TSA-FISH) previously used in Xenopus tropicalis [29-33], for detection of single-copy genes in Lepidoptera. We successfully localized the Ace-1 gene on both mitotic and meiotic chromosomes of the codling moth and confirmed its sex-linkage. Combination of BAC-FISH with reprobing protocol and TSA-FISH allowed us to add Ace-1 to the existing physical map of the codling moth $\mathrm{Z}$ chromosome. Furthermore, we have developed a protocol for two-colour TSA-FISH that may substantially facilitate comparative mapping in non-model organisms.

\section{Methods}

\section{Chromosome preparations}

We used Cydia pomonella specimens of a laboratory wild-type strain referred to as Krym-61 (for its origin, diet, and rearing conditions, see [23]). Spread chromosome preparations were made from male gonads of 4-5th instar larvae as described by Mediouni et al. [34]. Briefly, testes were dissected in a physiological solution, pre-treated for $10 \mathrm{~min}$ in a hypotonic solution $(0.075 \mathrm{M} \mathrm{KCl})$ and fixed in Carnoy fixative (ethanol/chloroform/acetic acid, 6:3:1) for $15 \mathrm{~min}$. Tissue was subsequently transferred into a drop of $60 \%$ acetic acid, dissociated with tungsten needles and spread on the slide using a heating plate at $45^{\circ} \mathrm{C}$. The preparations were passed through a graded ethanol series (70, 80, and 100\%; $30 \mathrm{~s}$ each) and stored at $-20^{\circ} \mathrm{C}$ until further use. 
FISH with bacterial artificial chromosomes (BAC-FISH) BAC clones $40 \mathrm{~B} 18$ and $12 \mathrm{O} 03$ containing the genes Nanchung (Nan) and Ribosomal protein PO (RpPO), respectively, were obtained from the codling moth BAC library constructed by GENEfinder Genomic Resource Laboratory (Texas A\&M University, College Station, TX, USA) (for details, see [26]). BAC-DNA was extracted using Qiagen Plasmid Midi Kit (Qiagen, Düsseldorf, Germany) and labelled by Cy3-dUTP (GE Healthcare, Buckinghamshire, UK) or ChromaTide Fluorescein-12dUTP (Invitrogen, Paisley, UK) using a Nick Translation Kit (Abbott Molecular, Des Plaines, IL, USA) as described by Nguyen et al. [26]. Two-colour BAC-FISH was performed according to Yoshido et al. [35]. The probe cocktail for one slide $(10 \mu \mathrm{L} ; 50 \%$ deionized formamide and $10 \%$ dextran sulphate in $2 x$ SSC buffer) contained 160-450 ng of each labelled BAC probe, $3 \mu \mathrm{g}$ of unlabelled sonicated genomic DNA used as a speciesspecific competitor and $25 \mu \mathrm{g}$ of sonicated salmon sperm DNA (Sigma-Aldrich, St. Louis, MO, USA). Reprobing protocol was adapted from Shibata et al. [36].

\section{FISH with tyramide signal amplification (TSA-FISH)}

Partial coding sequences of the Acetylcholinesterase 1 (Ace-1) ( 1300 bp) and Notch ( 1300 bp) genes were amplified by PCR as described in Nguyen et al. [26]. The PCR products were extracted from the gel using Wizard $^{\circledR}$ SV Gel and PCR Clean-Up System (Promega, Madison, WI, USA) and cloned into a pGEM ${ }^{\circledR}-\mathrm{T}$ Easy Vector (Promega). Plasmids were isolated from the bacteria using a NucleoSpin ${ }^{\circledR}$ Plasmid kit (Macherey-Nagel, Düren, Germany) and used as a template for PCR reamplification of the Ace-1 and Notch genes. Reamplified fragments purified by Wizard ${ }^{\circledR}$ SV Gel and PCR CleanUp System (Promega) were labelled for $1 \mathrm{~h} 45 \mathrm{~min}$ at $15^{\circ} \mathrm{C}$ with dinitrophenol-11-dUTP (DNP) (PerkinElmer, Waltham, MA, USA) or digoxigenin-11-dUTP alkali labile (DIG) (Roche Diagnostics, Mannheim, Germany) using a Nick Translation Kit (Abbot Molecular). For DIG-labelling, the same dNTP concentrations as for labelling of BAC DNA were used (see [26]). In case of DNP-labelling, manufacturer's recommendation was followed. Obtained probes were purified with illustra ProbeQuant G-50 Micro Columns (GE Healthcare).

The TSA-FISH experiments were performed according to Krylov et al. [30] with modifications. Slides were dehydrated in an ethanol series $(70,80$, and $100 \% ; 30 \mathrm{~s}$ each) and pre-treated with $50 \mu \mathrm{g} / \mathrm{mL}$ pepsin in $0.01 \mathrm{M}$ $\mathrm{HCl}$ at $37^{\circ} \mathrm{C}$ for $5 \mathrm{~min}, 2 \%$ formaldehyde freshly prepared from paraformadehyde at room temperature (RT) for $10 \mathrm{~min}, 1 \% \mathrm{H}_{2} \mathrm{O}_{2}$ in PBS at RT for $30 \mathrm{~min}$, and 100 $\mu \mathrm{g} / \mathrm{mL}$ RNase A in PBS at $37^{\circ} \mathrm{C}$ for 1 hour. After each pre-treatment, the slides were washed three times in PBS at RT for 5 min each. After the last washing, the slides were again dehydrated in an ethanol series (70, 80, and $100 \%$; 3 min each). The chromosomes were hybridized with $50 \mu \mathrm{L}$ of probe cocktail containing $50 \%$ deionized formamide, $10 \%$ dextran sulphate, and $40 \mathrm{ng}$ of probe in $2 x$ SSC. The probe cocktail was applied to chromosome preparation, covered with cover slip and denatured at $70^{\circ} \mathrm{C}$ for $5 \mathrm{~min}$. The slides were then placed in a humid chamber. Hybridization was carried out at $37^{\circ} \mathrm{C}$ for $12-16 \mathrm{~h}$.

After hybridization, the slides were washed three times in $50 \%$ formamide in $2 \times \mathrm{SSC}$ at $42^{\circ} \mathrm{C}$ for 5 min each, three times in $2 \mathrm{x}$ SSC at RT for 5 min each, and one time in TNT buffer $(0.1 \mathrm{M}$ Tris- $\mathrm{HCl} \mathrm{pH} 7.5,0.15 \mathrm{M}$ $\mathrm{NaCl}, 0.05 \%$ Tween-20) at RT for 5 min. The blocking of slides was carried out with $1 \mathrm{~mL}$ of TNB buffer per slide (0.1 M Tris- $\mathrm{HCl} \mathrm{pH} 7.5,0.15 \mathrm{M} \mathrm{NaCl}, 0.5 \%$ Blocking Reagent; PerkinElmer) at RT for $30 \mathrm{~min}$. The excess of buffer was poured off and the slides were incubated at RT for one hour with $1 \mathrm{~mL}$ of anti-DIG-POD (Roche Diagnostics) or anti-DNP-HRP conjugate (PerkinElmer) diluted 1:1000 in TNB buffer. The slides were washed three times in TNT buffer for 5 min each. Tyramide amplification was carried out using the TSA Plus Fluorescence Kit with either $\mathrm{Cy} 3$ or fluorescein derivative (PerkinElmer) according to the instructions of the manufacturer. One hundred $\mu \mathrm{L}$ of the tyramide working solution was applied to a slide and incubated in a humid chamber for $15 \mathrm{~min}$. The slides were then washed three times in TNT buffer for 5 min each and one time in 1\% Kodak PhotoFlo (Sigma-Aldrich) in $\mathrm{H}_{2} \mathrm{O}$ for $1 \mathrm{~min}$. The preparations were mounted in antifade based on DABCO (Sigma-Aldrich) (for composition, see [34]) containing $0.5 \mathrm{mg} / \mathrm{mL}$ DAPI (4',6-diamidino-2phenylindole) (Sigma-Aldrich).

In the case of two-colour TSA-FISH, probes were detected sequentially as shown e.g. by van Gijlswijk et al. [37] and Denkers et al. [38]. After last washing with TNT buffer, antibody conjugated peroxidase from the previous reaction was quenched with $1 \% \mathrm{H}_{2} \mathrm{O}_{2}$ in PBS at RT for $30 \mathrm{~min}$. The slides were washed three times in TNT buffer at RT for 5 min each, and the blocking, antibody incubation, and signal amplification steps were repeated.

\section{Microscopy and image processing}

Chromosome preparations were observed in a Zeiss Axioplan 2 microscope (Carl Zeiss, Jena, Germany) equipped with appropriate fluorescence filter sets. Black-and-white images were captured with an Olympus CCD monochrome camera XM10 equipped with cellSens 1.9 digital imaging software (Olympus Europa Holding, Hamburg, Germany). The images were pseudocoloured and superimposed with Adobe Photoshop 10.0.1 (Adobe Systems, San Jose, CA, USA). Image analysis was performed using 
freeware ImageJ (National Institutes of Health, Bethesda, MD, USA).

\section{Results}

We adapted the protocol of TSA-FISH, i.e. fluorescence in situ hybridization coupled with tyramide signal amplification, originally customized for the localization of genes on large mitotic metaphase chromosomes of the frog Хепориs tropicalis [30], for lepidopteran chromosomes. However, holokinetic chromosomes of Lepidoptera are unfavourable for cytogenetic analyses in mitotic metaphase due to their small size, the dot-like appearance, and the absence of any morphological landmarks such as localized centromeres. Therefore, much longer meiotic bivalents in the pachytene stage are employed for chromosome research and especially for FISH mapping (reviewed in [39-41]). Since pachytene bivalents are less resistant than compact mitotic chromosomes to particular FISH procedures due to their specific morphology, the following modifications of the Krylov et al. protocol [30] were applied. The duration of the slide pre-treatment with pepsin and formaldehyde was shortened in order to preserve the structure of the pachytene chromosomes, and an extra pre-treatment with RNase A was included to reduce background noise. Dextran sulphate was added to the hybridization mixture to increase the effective probe concentration and accelerate the hybridization rate, thus obtaining better quality signals. Finally, denaturation of the chromosomes and the probes was carried out at $70^{\circ} \mathrm{C}$ instead of $80^{\circ} \mathrm{C}$ to reduce its negative effect on the chromosome morphology.

TSA-FISH allowed the detection of unique sequences as short as $\sim 1300$ bp on both mitotic and meiotic chromosomes of the codling moth. As previously reported, this technique provided unbalanced signals, i.e. signals, which often differed in their intensity between homologous loci or signals that were observed only on one of the homologous chromosomes (Figure 1a, b, d and Figure 1e, respectively), most likely due to chromatin structure $[28,42]$. However, this obstacle is circumvented as pachytene bivalents formed by paired homologues are usually used for chromosome mapping in Lepidoptera [43-48]. The signal frequency, defined as a proportion of chromosome complements bearing at least one signal per bivalent, was higher than $60 \%$. TSA-FISH thus represents a reliable means for detection of unique sequences on lepidopteran chromosomes.

The probe derived from partial coding sequence of the Acetylcholinesterase 1 (Ace-1) gene provided a clear and intense hybridization signal localized nearly in the middle of a male pachytene bivalent (Figure 1a). Chromosomal position of the Ace-1 was also confirmed by TSA-FISH performed on male mitotic chromosomes, which mapped Ace-1 to an interstitial region of the two largest elements in the codling moth karyotype (Figure 1b) identified previously as the $\mathrm{Z}$ sex chromosomes [23,26]. Comparison of the physical map of the Cydia pomonella $\mathrm{Z}$ chromosome with a reference genome of the silkworm Bombyx mori [26] suggests that Ace-1 is located between two anchoring loci, Ribosomal protein PO (RpPO) and Nanchung (Nan). In order to test this prediction we combined BAC-FISH and TSA-FISH in two subsequent steps. First, BAC-derived probes containing $\mathrm{RpPO}$ and $\mathrm{Nan}$ were hybridized to male pachytene chromosomes of the codling moth. As expected, both markers were localized interstitially on a single pachytene bivalent (Figure 1c). Then the slides were stripped and reprobed using TSAFISH protocol. The Ace-1 gene mapped between the two anchoring genes adjacent to RpPO (Figure 1c). Physical distances between the genes were measured using ImageJ and relative position of Ace-1 was calculated, which allowed its integration in the physical map of the codling moth $\mathrm{Z}$ chromosome (Figure 2).

TSA-FISH could, in theory, be used for simultaneous detection of two markers, as both signals are expected to be present in about one third of nuclei due to high signal frequencies. For the two-colour TSA-FISH, sequential detection of probes labelled by DIG and DNP was adopted $[37,38]$. The Notch gene located in a sub-terminal region of the codling moth $\mathrm{Z}$ chromosome [26] (Figure 1d) was used along with Ace-1 to demonstrate feasibility of this approach. Two-colour TSA-FISH indeed mapped both genes to the $\mathrm{Z}$ chromosome bivalent in pachytene spermatocytes of the codling moth (Figure 1e). However, a substantial drop in the frequency of hybridization signals was observed after the second detection round of TSA-FISH. Since signal frequencies do not differ for particular haptens or fluorochromes used (not shown), the observed decrease in TSA-FISH efficiency was probably due to damage caused to hapten molecules while quenching the peroxidase activity with $\mathrm{H}_{2} \mathrm{O}_{2}$ after the first detection round.

\section{Discussion}

A sequenced genome of the silkworm Bombyx mori [49-51] integrated with its BAC-based linkage map [52] spurred comparative genomic studies in Lepidoptera. BAC clones have been widely used for testing synteny of genes between silkworm and other lepidopteran species by BACFISH $[26,35,43,44,47,48]$ as they provide reliable hybridization signals due to the large insert size ranging from 100 to $200 \mathrm{kbp}[44,53]$. Yet the BAC libraries are available only for a handful of species, and their construction, handling and screening remains rather expensive and laborious. Genes have also been physically mapped by conventional FISH with probes derived from cDNA (cDNA-FISH). Although this technique has been routinely utilized in vertebrates (e.g. [54-57]), in Lepidoptera it was used only for the identification of chromosomes involved in the 


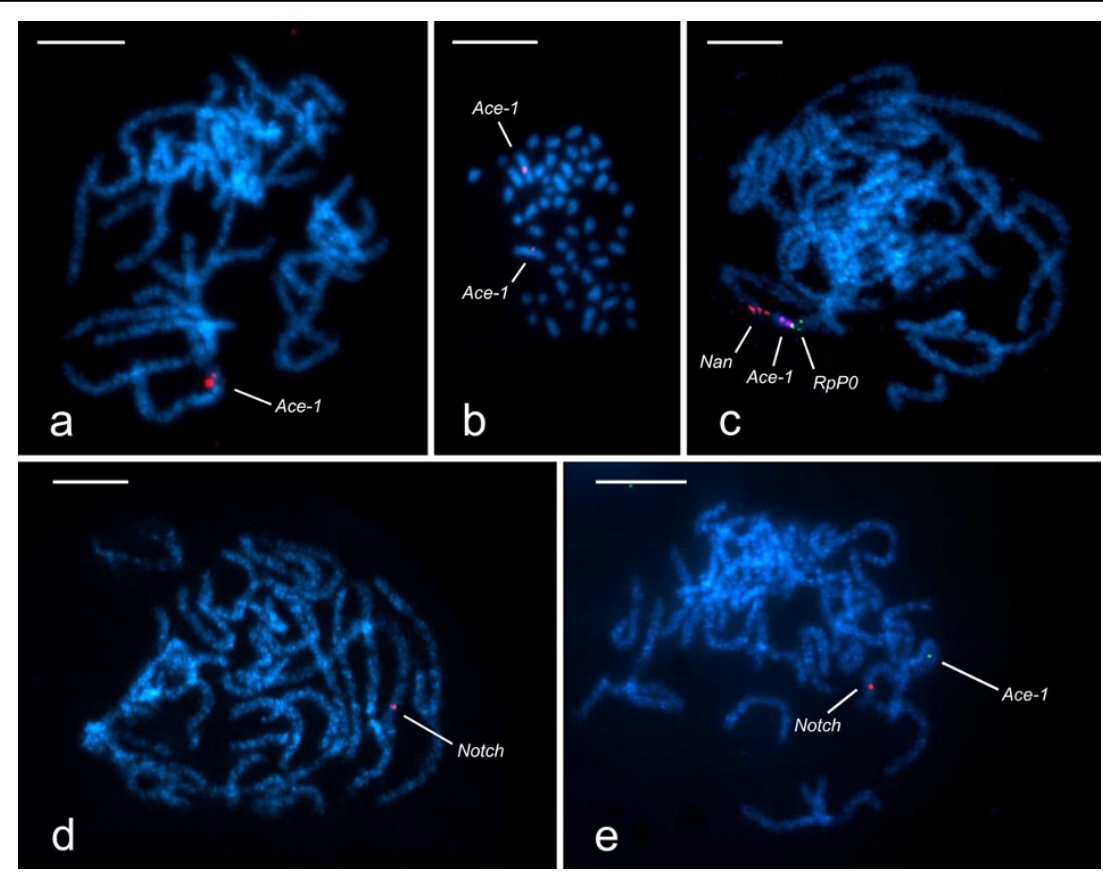

Figure 1 Mapping of genes on chromosome preparations from testes of the codling moth, Cydia pomonella. Chromosomes were counterstained by DAPI (light blue). Hybridization signals (green, red, and violet) mark the physical position of genes under study (Ace-1, Nan, RpPO, and Notch). (a) Ace-1 localized on one bivalent in the pachytene spermatocyte complement by TSA-FISH; note two discrete but unbalanced (one large and one small) hybridization signals, each representing the Ace-1 locus on one homologous chromosome. (b) TSA-FISH with the Ace-1 probe revealed a nearly middle position of the Ace-1 locus on two largest elements of male mitotic metaphase corresponding to the $\mathbf{Z}$ chromosomes. (c) Two Z-linked genes, RpPO and Nan, were mapped to the Z chromosome bivalent in the pachytene nucleus by BACFISH. Subsequent TSA-FISH localized the Ace-1 gene between these two markers. (d) The Notch gene mapped to a subterminal region of the $Z$ chromosome bivalent in pachytene chromosomes by TSA-FISH. (e) Two single copy genes, Ace-1 and Notch, mapped to the Z chromosome bivalent in pachytene chromosomes by two-colour TSA-FISH. (Scale bar: $10 \mu \mathrm{m}$.)

evolution of the neo-sex chromosome systems in populations of wild silkmoths, Samia cynthia ssp. [45]. However, Vicoso et al. [58] found inconsistencies between results of cDNA-FISH and actual genomic data in snakes, which questioned this approach. Recently, up to $40 \mathrm{kbp}$ long fosmid clones got in focus. Since fosmid libraries are easier to construct, they are expected to facilitate comparative gene mapping in Lepidoptera $[46,47,59]$. Since no genomic libraries are needed for fluorescence in situ hybridization with tyramide signal amplification (TSA-FISH) it has a potential to further facilitate cost-effective comparative genomic studies in non-model species.

The TSA-FISH protocol employed in this study, adapted to fine structures of meiotic chromosomes of
Lepidoptera, allowed us to overcome the detection constraints of conventional FISH and visualize unique, about 1300 bp long sequences (Figure 1a-e). With TSAFISH applied to chromosomes of the codling moth, we achieved hybridization signal frequencies of more than $60 \%$ at fluorescence intensities comparable to those of BAC clones (Figure 1c). Providing that an average size of a codling moth BAC clone insert is about $140 \mathrm{kbp}$ [26], sensitivity of the probe detection by TSA-FISH was presumably enhanced about 100 times, reaching the upper range reported previously $[60,61]$.

The potential of TSA-FISH was clearly demonstrated by mapping the Acetylcholinesterase 1 gene (Ace-1) on the codling moth $\mathrm{Z}$ chromosome (Figure 1b,c,e).

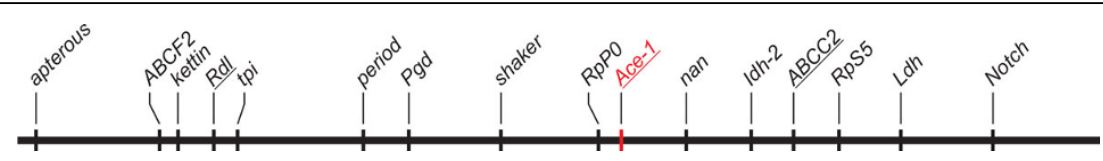

Figure 2 Diagram integrating Ace-1 into a physical map of the codling moth Z chromosome. The gene-based physical map was adopted from Nguyen et al. [26]. The mean relative position of Ace-1 was calculated from physical distances between Ace-1 and RpPO hybridization signals related to physical distances between RpPO and Nan in $10 \mathrm{ZZ}$ bivalents. Major genes conferring insecticide resistance are underlined, Ace1 is in red. 
Nguyen et al. [26] physically mapped the codling moth $\mathrm{Z}$ chromosome and found out that it arose from a fusion between an ancestral $\mathrm{Z}$ sex chromosome and an autosome corresponding to the silkworm chromosome 15 . The B. mori chromosome 15 was shown to harbour several genes conferring resistance to chemical and biological insecticides, namely Resistance to dieldrin (Rdl), $A B C$ transporter $C 2(A B C C 2)$ and Ace-1. The $A B C C 2$ and $R d l$ genes were both unambiguously mapped to the codling moth $\mathrm{Z}$ chromosome by means of BAC-FISH. However, no BAC clone was available for the Ace-1 gene, which was assigned to the $\mathrm{Z}$ sex chromosome indirectly by quantitative PCR (qPCR) analysis of male and female gene dose. Yet uncertainty remained as it was shown that a chromosomal region adjacent to Ace-1 was translocated to an autosome in a common ancestor of the subfamily Olethreutinae [26]. TSA-FISH results confirmed the conclusions of qPCR analysis and localized Ace-1 to the expected chromosomal locus delimited by two anchoring genes, Ribosomal protein $P O$ and Nanchung (Figure 1c, Figure 2).

Nguyen et al. [26] argued that Z-linked mutations conferring resistance can be fixed faster in a pest population due to their hemizygosity in the females (cf. [62]). Although $A B C C 2$ mutations conferring resistance to Bacillus thuringiensis toxin $\mathrm{Cry} 1 \mathrm{Ab}$ were indeed reported to be recessive [63-65], the insensitivity conferred by Ace-1 is supposed to be semidominant to dominant [66]. However, Bourguet et al. [67] analyzed Ace alleles conferring insecticide resistance in mosquito strains and found out that dominance levels differ between strains, ranging from recessiveness to dominance. The authors explained the recessiveness of Aceconferred resistance by activity of insensitive Ace. When Ace activity is low, heterozygotes $\left(\mathrm{A}^{\mathrm{R}} \mathrm{A}^{\mathrm{S}}\right.$, where $\mathrm{A}$ stands for autosome) do not have sufficient amount of insensitive Ace compared to homozygotes $\left(\mathrm{A}^{\mathrm{R}} \mathrm{A}^{\mathrm{R}}\right)$, and thus display a lower tolerance to insecticide. In tortricids, there would be no difference in activity of insensitive Ace-1 between heterozygous males $\left(Z^{R} Z^{S}\right)$ and hemizygous females $\left(\mathrm{Z}^{\mathrm{R}} \mathrm{W}\right)$ due to the sex-linkage of the Ace-1 gene and absence of global dosage compensation ([68], but see $[69,70])$. Therefore, there is seemingly no way to fix a recessive mutation conferring Ace-1 insensitivity. Yet Ace-1 insensitivity was reported to be sex-linked and recessive in another tortricid pest, the oriental fruit moth Grapholita molesta [71]. Kanga et al. [71] stated that the "inheritance of the $A C h E$ factor was either recessive or incompletely dominant depending on the direction of the cross". However, the authors misinterpreted the data since the Ace-1 inhibition in the $\mathrm{F}_{1}$ progeny from $\left(\mathrm{R} O \times \mathrm{SO}^{r}\right)$ crosses reflected its sex-linkage rather than its incomplete dominance as $F_{1}$ females from this cross are susceptible because they inherit the
$\mathrm{Z}$ chromosome from susceptible male and W chromosome from resistant female. According to the results of $(\mathrm{S} q \times \mathrm{Ro})$ cross the Ace-1 insensitivity is recessive. As hypothesised by Bourguet et al. [67] , recessiveness of Ace-1 insensitivity was most likely allowed by a female specific modifier compensating for a lower dosage of Ace-1, which most likely evolved in G. molesta as suggested by similar Ace-1 activity between males and females of both susceptible and resistant strains [71].

To conclude, TSA-FISH represents a reliable technique for physical mapping of genes on chromosomes of moths and butterflies. In future, this technique can be combined with BAC-FISH protocol (Figure 1c) and used for physical localization of transgene cassettes, such as that containing a dominant cold sensitive mutant allele of the Notch gene on sex chromosomes of transgenic lines of the codling moth or other lepidopteran species, if available. Furthermore, a developed protocol for twocolour TSA-FISH represents a feasible approach for comparative mapping of genes on the holokinetic chromosomes of moths and butterflies. After necessary optimization, the two-colour TSA-FISH might become a powerful tool which will allow cost-effective synteny mapping in non-model organisms.

\section{List of abbreviations used}

$A B C C 2$ : ABC transporter C2 gene; Ace-1: Acetylcholinesterase 1 gene; BAC: bacterial artificial chromosome; BAC-FISH: fluorescence in situ hybridization with bacterial artificial chromosome probes; DCLM: dominant conditional lethal mutation; FISH: fluorescence in situ hybridization; Nan: Nanchung gene; PCR: polymerase chain reaction; qPCR: quantitative polymerase chain reaction; Rdl: Resistance to dieldrin gene; RpPO: Ribosomal protein PO gene; RT: room temperature; SIT: sterile insect technique; TSA: tyramide signal amplification; TSA-FISH: fluorescence in situ hybridization with tyramide signal amplification.

\section{Competing interests}

The authors declare that they have no competing interests.

\section{Authors' contributions}

LZCP adapted the TSA-FISH protocol to lepidopteran chromosomes. LZCP and PN performed the experiments and analyzed the data. JS participated in preparation of chromosome spreads, FISH probes, and reagents. LZCP, PN and FM conceived this work and wrote the paper. All authors read and approved the final manuscript.

\section{Acknowledgements}

We thank Marie Korchová for technical assistance. This research was part of a Coordinated Research Project of the IAEA, Vienna (Research Agreement No. 15838). Experiments were funded by grants $14-22765$ S (given to FM) and 14-35819P (given to PN) of the Czech Science Foundation. LZCP was supported from the project Postdok_BIOGLOBE (CZ.1.07/2.3.00/30.0032) cofinanced by the European Social Fund and the state budget of the Czech Republic. JŠ acknowledges support from the GAJU 052/2013/P grant of the Grant Agency of the University of South Bohemia.

This article has been published as part of BMC Genetics Volume 15

Supplement 2, 2014: Development and evaluation of improved strains of insect pests for SIT. The full contents of the supplement are available online at http://www.biomedcentral.com/bmcgenet/supplements/15/S2. Publication of this supplement was funded by the International Atomic Energy Agency. The peer review process for articles published in this supplement was overseen by the Supplement Editors in accordance with 
BioMed Central's peer review guidelines for supplements. The Supplement Editors declare that they have no competing interests.

\section{Authors' details}

${ }^{1}$ Institute of Entomology, Biology Centre ASCR, Branišovská 31, 37005 České Budějovice, Czech Republic. ${ }^{2}$ Faculty of Science, University of South Bohemia, Branišovská 31, 37005 České Budějovice, Czech Republic.

Published: 1 December 2014

\section{References}

1. Barnes MM: Codling moth occurrence, host race formation, and damage. In World Crop Pests. Tortricid Pests. Their Biology, Natural Enemies and Control. Amsterdam: Elsevier; Van der Geest LPS, Evenhuis HH 1991:313-327.

2. Wearing $\mathrm{CH}$, Hansen JD, Whyte C, Miller CE, Brown J: The potential for spread of codling moth (Lepidoptera: Tortricidae) via commercial sweet cherry fruit: a critical review and risk assessment. Crop Prot 2001, 20:465-488.

3. Men QL, Chen MH, Zhang YL, Feng JN: Genetic structure and diversity of a newly invasive species, the codling moth, Cydia pomonella (L.) (Lepidoptera: Tortricidae) in China. Biol Invasions 2013, 15:447-458.

4. Dunley JE, Welter SC: Correlated insecticide cross-resistance in azinphosmethyl resistant codling moth (Lepidoptera: Tortricidae). J Econ Entomol 2000, 93:955-962.

5. Reyes M, Franck P, Charmillot PJ, Ioriatti C, Olivares J, Pasqualini E, Sauphanor B: Diversity of insecticide resistance mechanisms and spectrum in European populations of the codling moth, Cydia pomonella. Pest Manag Sci 2007, 63:890-902.

6. Reyes M, Franck P, Olivares J, Margaritopoulos J, Knight A, Sauphanor B: Worldwide variability of insecticide resistance mechanisms in the codling moth, Cydia pomonella L. (Lepidoptera: Tortricidae). Bull Entomol Res 2009, 99:359-369.

7. Arthurs SP, Lacey LA, Miliczky ER: Evaluation of the codling moth granulovirus and spinosad for codling moth control and impact on nontarget species in pear orchards. Biol Control 2007, 41:99-109.

8. Steinmann KP, Zhang M, Grant JA: Does use of pesticides known to harm natural enemies of spider mites (Acari: Tetranychidae) result in increased number of miticide applications? An examination of California walnut orchards. J Econ Entomol 2011, 104:1496-1501.

9. Devine GJ, Furlong MJ: Insecticide use: Contexts and ecological consequences. Agric Human Values 2007, 24:281-306.

10. Dyck VA, Hendrichs J, Robinson AS: Sterile Insect Technique. Principles and Practice in Area-wide Integrated Pest Management. Dordrecht: Springer; 2005

11. Proverbs MD, Newton JR, Campbell CJ: Codling moth - a pilot program of control by sterile insect release in British Columbia. Can Entomol 1982 114:363-376

12. Dyck VA, Graham SA, Bloem SK: Implementation of the sterile insect release programme to eradicate the codling moth, Cydia pomonella (L.) (Lepidoptera: Olethreutidae) in British Columbia, Canada. In Management of Insect Pests: Nuclear and Related Molecular and Genetic Techniques. Proceedings of an International Symposium Organised by the IAEAFFAO: 19-23 October 1992; Vienna. Vienna: IAEA;Howard-Kitto P, Kelleher RF, Ramesh GV 1993:285-297.

13. Bloem S, McCluskey A, Fugger R, Arthur S, Wood S, Carpenter J: Suppression of the codling moth Cydia pomonella in British Columbia, Canada using an area-wide integrated approach with an SIT component. In Area-wide Control of Insect Pests. From Research to Field Implementation. Dordrecht: Springer;Vreysen MJB, Robinson AS, Hendrichs J 2007:591-601.

14. Knipling EF: Possibilities of insect control or eradication through the use of sexually sterile males. J Econ Entomol 1955, 48:459-462

15. Vreysen MJB, Carpenter JE, Marec F: Improvement of the sterile insect technique for codling moth Cydia pomonella (Linnaeus) (Lepidoptera Tortricidae) to facilitate expansion of field application. J Appl Entomol 2010, 134:165-181.

16. Mclnnis DO, Tam S, Grace C, Miyashita D: Population suppression and sterility rates induced by variable sex-ratio, sterile insect releases of Ceratitis capitata (Diptera, Tephritidae) in Hawaii. Ann Entomol Soc Am 1994, 87:231-240.

17. Hendrichs J, Franz G, Rendon P: Increased effectiveness and applicability of the sterile insect technique through male-only releases for control of
Mediterranean fruit flies during fruiting seasons. J Appl Entomol 1995, 119:371-377.

18. Rendón P, Mclnnis D, Lance D, Stewart J: Medfly (Diptera: Tephritidae) genetic sexing: Large-scale field comparison of males-only and bisexual sterile fly releases in Guatemala. J Econ Entomol 2004, 97:1547-1553.

19. Knipple DC: Prospects for the use of transgenic approaches to improve the efficacy of the Sterile Insect Technique (SIT) for control of the codling moth Cydia pomonella Linnaeus (Lepidoptera: Tortricidae). Crop Prot 2013, 44:142-146.

20. Marec F, Neven LG, Robinson AS, Vreysen M, Goldsmith MR, Nagaraju J, Franz G: Development of genetic sexing strains in Lepidoptera: from traditional to transgenic approaches. J Econ Entomol 2005, 98:248-259.

21. Marec F, Neven LG, Fuková I: Developing transgenic sexing strains for the release of non-transgenic sterile male codling moths Cydia pomonella. In Area-wide Control of Insect Pests. From Research to Field Implementation. Dordrecht: Springer; Vreysen MJB, Robinson AS, Hendrichs J 2007:103-111.

22. Fuková I, Neven LG, Bárcenas NM, Gund NA, Dalíková M, Marec F: Rapid assessment of the sex of codling moth Cydia pomonella (Linnaeus) (Lepidoptera: Tortricidae) eggs and larvae. J Appl Entomol 2009, 133:249-261

23. Fuková I, Nguyen P, Marec F: Codling moth cytogenetics: karyotype, chromosomal location of rDNA, and molecular differentiation of sex chromosomes. Genome 2005, 48:1083-1092.

24. Šíchová J, Nguyen P, Dalíková M, Marec F: Chromosomal evolution in tortricid moths: Conserved karyotypes with diverged features. PLoS One 2013, 8:e64520.

25. Fuková I, Traut W, Vítková M, Nguyen P, Kubíčková S, Marec F: Probing the W chromosome of the codling moth, Cydia pomonella, with sequences from microdissected sex chromatin. Chromosoma 2007, 116:135-145.

26. Nguyen $P$, Sýkorová $M$, Šíchová J, Kůta V, Dalíková M, Čapková Frydrychová R, Neven LG, Sahara K, Marec F: Neo-sex chromosomes and adaptive potential in tortricid pests. Proc Natl Acad Sci USA 2013, 110:6931-6936.

27. Speel EJM, Hopman AHN, Komminoth P: Signal amplification for DNA and mRNA. In In Situ Hybridization Protocols. Volume 123. Totowa: Humana Press Inc:Darby IA 2000:195-216, Methods in Molecular Biology.

28. Kirov I, Van Laere K, De Riek J, De Keyser E, Van Roy N, Khrustaleva L: Anchoring linkage groups of the Rosa genetic map to physical chromosomes with Tyramide-FISH and EST-SNP markers. PLoS One 2014, 9:e95793.

29. Courtet M, Flajnik M, Du Pasquier L: Major histocompatibility complex and immunoglobulin loci visualized by in situ hybridization on Xenopus chromosomes. Dev Comp Immunol 2001, 25:149-157.

30. Krylov V, Mácha J, Tlapáková T, Takáč M, Jonák J: The c-src1 gene visualized by in situ hybridization on Xenopus laevis chromosomes. Cytogenet Genome Res 2003, 103:169-172.

31. Krylov V, Tlapakova T, Macha J: Localization of the single copy gene Mdh2 on Xenopus tropicalis chromosomes by FISH-TSA. Cytogenet Genome Res 2007, 116:110-112.

32. Mácha J, Teichmanová R, Sater AK, Wells DE, Tlapáková T, Zimmerman LB, Krylov V: Deep ancestry of mammalian $X$ chromosome revealed by comparison with the basal tetrapod Xenopus tropicalis. BMC Genomic 2012, 13:315.

33. Seifertova E, Zimmerman LB, Gilchrist MJ, Macha J, Kubickova S, Cernohorska H, Zarsky V, Owens NDL, Sesay AK, Tlapakova T, Krylov V: Efficient high-throughput sequencing of a laser microdissected chromosome arm. BMC Genomics 2013, 14:357.

34. Mediouni J, Fuková I, Frydrychová R, Dhouibi MH, Marec F: Karyotype, sex chromatin and sex chromosome differentiation in the carob moth Ectomyelois ceratoniae (Lepidoptera: Pyralidae). Caryologia 2004 57:184-194.

35. Yoshido A, Bando H, Yasukochi Y, Sahara K: The Bombyx mori karyotype and the assignment of linkage groups. Genetics 2005, 170:675-685.

36. Shibata F, Sahara K, Naito Y, Yasukochi Y: Reprobing multicolor FISH preparations in lepidopteran chromosome. Zool Sci 2009, 26:187-190.

37. van Gijlswijk RPM, Zijlmans HJMAA, Wiegant J, Bobrow MN, Erickson TJ, Adler KE, Tanke HJ, Raap AK: Fluorochrome-labeled tyramides: Use in immunocytochemistry and fluorescence in situ hybridization. $J$ Histochem Cytochem 1997, 45:375-382.

38. Denkers N, García-Villalba P, Rodesch CK, Nielson KR, Mauch TJ: FISHing for chick genes: Triple-label whole-mount fluorescence in situ hybridization 
detects simultaneous and overlapping gene expression in avian embryos. Dev Dyn 2004, 229:651-657.

39. Traut W, Sahara K, Marec F: Sex chromosomes and sex determination in Lepidoptera. Sex Dev 2007, 1:332-346

40. Marec F, Sahara K, Traut W: Rise and fall of the W chromosome in Lepidoptera. In Molecular Biology and Genetics of the Lepidoptera. Boca Raton: CRC Press:Goldsmith MR, Marec F 2010:49-63.

41. Sahara K, Yoshido A, Traut W: Sex chromosome evolution in moths and butterflies. Chromosome Res 2012, 20:83-94.

42. Rego A, Marec F: Telomeric and interstitial telomeric sequences in holokinetic chromosomes of Lepidoptera: Telomeric DNA mediates association between postpachytene bivalents in achiasmatic meiosis of females. Chromosome Res 2003, 11:681-694.

43. Sahara K, Yoshido A, Marec F, Fuková I, Zhang HB, Wu CC, Goldsmith MR, Yasukochi Y: Conserved synteny of genes between chromosome 15 of Bombyx mori and a chromosome of Manduca sexta shown by five-color BAC-FISH. Genome 2007, 50:1061-1065.

44. Yasukochi Y, Tanaka-Okuyama M, Shibata F, Yoshido A, Marec F, Wu CC Zhang HB, Goldsmith MR, Sahara K: Extensive conserved synteny of genes between the karyotypes of Manduca sexta and Bombyx mori revealed by BAC-FISH mapping. PLoS One 2009, 4:e7465.

45. Yoshido A, Sahara K, Marec F, Matsuda Y: Step-by-step evolution of neosex chromosomes in geographical populations of wild silkmoths, Samia cynthia ssp. Heredity 2011, 106:614-624.

46. Yoshido A, Yasukochi Y, Sahara K: Samia cynthia versus Bombyx mori: Comparative gene mapping between a species with a low-number karyotype and the model species of Lepidoptera. Insect Biochem Mol Biol 2011, 41:370-377.

47. Sahara K, Yoshido A, Shibata F, Fujikawa-Kojima N, Okabe T, TanakaOkuyama M, Yasukochi Y: FISH identification of Helicoverpa armigera and Mamestra brassicae chromosomes by BAC and fosmid probes. Insect Biochem Mol Biol 2013, 43:644-653.

48. Van't Hof AE, Nguyen P, Dalíková M, Edmonds N, Marec F, Saccheri IJ: Linkage map of the peppered moth, Biston betularia (Lepidoptera, Geometridae): a model of industrial melanism. Heredity 2013, 110:283-295.

49. Mita K, Kasahara M, Sasaki S, Nagayasu Y, Yamada T, Kanamori H, Namiki N, Kitagawa M, Yamashita H, Yasukochi Y, Kadono-Okuda K, Yamamoto K Ajimura M, Ravikumar G, Shimomura M, Nagamura Y, Shin-I T, Abe H, Shimada T, Morishita S, Sasaki T: The genome sequence of silkworm Bombyx mori. DNA Research 2004, 11:27-35.

50. Xia Q, Zhou Z, Lu C, Cheng D, Dai F, Li B, Zhao P, Zha X, Cheng T, Chai C Pan G, Xu J, Liu C, Lin Y, Qian J, Hou Y, Wu Z, Li G, Pan M, Li C, Shen Y, Lan X, Yuan L, Li T, Xu H, Yang G, Wan Y, Zhu Y, Yu M, Shen W, et al: A draft sequence for the genome of the domesticated silkworm (Bombyx mori). Science 2004, 306:1937-1940.

51. The International Silkworm Genome Consortium: The genome of a lepidopteran model insect, the silkworm Bombyx mori. Insect Biochem Mol Biol 2008, 38:1036-1045.

52. Yamamoto K, Nohata J, Kadono-Okuda K, Narukawa J, Sasanuma M, Sasanuma S, Minami H, Shimomura M, Suetsugu Y, Banno Y, Osoegawa K, de Jong PJ, Goldsmith MR, Mita K: A BAC-based integrated linkage map of the silkworm Bombyx mori. Genome Biol 2008, 9:R21.

53. Janes DE, Valenzuela N, Ezaz T, Amemiya C, Edwards SV: Sex chromosome evolution in amniotes: Applications for bacterial artificial chromosome libraries. J Biomed Biotechnol 2011, 132975.

54. Nanda I, Zend-Ajusch E, Shan Z, Grützner F, Schartl M, Burt DW, Koehler M, Fowler VM, Goodwin G, Schneider WJ, Mizuno S, Dechant G, Haaf T, Schmid M: Conserved synteny between the chicken Z sex chromosome and human chromosome 9 includes the male regulatory gene DMRT1: a comparative (re)view on avian sex determination. Cytogenet Cell Genet 2000, 89:67-78

55. Matsuda Y, Nishida-Umehara C, Tarui H, Kuroiwa A, Yamada K, Isobe T, Ando J, Fujiwara A, Hirao Y, Nishimura O, Ishijima J, Hayashi A, Saito T, Murakami T, Murakami Y, Kuratani S, Agata K: Highly conserved linkage homology between birds and turtles: Bird and turtle chromosomes are precise counterparts of each other. Chromosome Res 2005, 13:601-615.

56. Matsubara K, Tarui H, Toriba M, Yamada K, Nishida-Umehara C, Agata K, Matsuda Y: Evidence for different origin of sex chromosomes in snakes, birds, and mammals and step-wise differentiation of snake sex chromosomes. Proc Natl Acad Sci USA 2006, 103:18190-18195.
57. Kawai A, Nishida-Umehara C, Ishijima J, Tsuda Y, Ota H, Matsuda Y: Different origins of bird and reptile sex chromosomes inferred from comparative mapping of chicken Z-linked genes. Cytogenet Genome Res 2007, 117:92-102.

58. Vicoso B, Emerson JJ, Zektser Y, Mahajan S, Bachtrog D: Comparative sex chromosome genomics in snakes: Differentiation, evolutionary strata, and lack of global dosage compensation. PLOS Biol 2013, 11:e1001643.

59. Kamimura M, Tateishi K, Tanaka-Okuyama M, Okabe T, Shibata F, Sahara K, Yasukochi Y: EST sequencing and fosmid library construction in a nonmodel moth, Mamestra brassicae, for comparative mapping. Genome 2012, 55:775-781.

60. Speel EJM, Hopman AHN, Komminoth P: Amplification methods to increase the sensitivity of in situ hybridization: Play CARD(S). J Histochem Cytochem 1999, 47:281-288.

61. Khrustaleva LI, Kik C: Localization of single-copy T-DNA insertion in transgenic shallots (Allium cepa) by using ultra-sensitive FISH with tyramide signal amplification. Plant $J$ 2001, 25:699-707.

62. Orr HA: The population genetics of beneficial mutations. Philos Trans $R$ Soc Lond B Biol Sci 2010, 365:1195-1201.

63. Gahan $L$, Pauchet $Y$, Vogel $H$, Heckel DG: An ABC transporter mutation is correlated with insect resistance to Bacillus thuringiensis Cry1Ac toxin. PLoS Genet 2010, 6:e1001248.

64. Baxter SW, Badenes-Pérez FR, Morrison A, Vogel H, Crickmore N, Kain W, Wang P, Heckel DG, Jiggins CD: Parallel evolution of Bacillus thuringiensis toxin resistance in Lepidoptera. Genetics 2011, 189:675-679.

65. Atsumi S, Miyamoto K, Yamamoto K, Narukawa J, Kawai S, Sezutsu H, Kobayashi I, Uchino K, Tamura T, Mita K, Kadono-Okuda K, Wada S, Kanda K, Goldsmith MR, Noda H: Single amino acid mutation in an ATP-binding cassette transporter gene causes resistance to $\mathrm{Bt}$ toxin $\mathrm{Cry} 1 \mathrm{Ab}$ in the silkworm, Bombyx mori. Proc Natl Acad Sci USA 2012, 109:E1591-E1598.

66. Bourguet D, Prout M, Raymond M: Dominance of insecticide resistance presents a plastic response. Genetics 1996, 143:407-416.

67. Bourguet D, Lenormand T, Guillemaud T, Marcel V, Fournier D, Raymond M: Variation of dominance of newly arisen adaptive genes. Genetics 1997, 147:1225-1234

68. Harrison PW, Mank JE, Wedell N: Incomplete sex chromosome dosage compensation in the Indian meal moth, Plodia interpunctella, based on de novo transcriptome assembly. Genome Biol Evol 2012, 4:1118-1126.

69. Kiuchi T, Koga H, Kawamoto M, Shoji K, Sakai H, Arai Y, Ishihara G, Kawaoka S, Sugano S, Shimada T, Suzuki Y, Suzuki MG, Katsuma S: A single female-specific piRNA is the primary determiner of sex in the silkworm Nature 2014, 509:633-636.

70. Smith G, Chen YR, Blissard GW, Briscoe AD: Complete dosage compensation and sex-biased gene expression in the moth Manduca sexta. Genome Biol Evol 2014, 6:526-537.

71. Kanga LHB, Pree DJ, Plapp FW, van Lier JL: Sex-linked altered acetylcholinesterase resistance to carbamate insecticides in adults of the oriental fruit moth, Grapholita molesta (Lepidoptera: Tortricidae). Pestic Biochem Physiol 2001, 71:29-39.

doi:10.1186/1471-2156-15-S2-S15

Cite this article as: Carabajal Paladino et al.: Mapping of single-copy genes by TSA-FISH in the codling moth, Cydia pomonella. BMC Genetic 2014 15(Suppl 2):S15

\section{Submit your next manuscript to BioMed Central and take full advantage of:}

- Convenient online submission

- Thorough peer review

- No space constraints or color figure charges

- Immediate publication on acceptance

- Inclusion in PubMed, CAS, Scopus and Google Scholar

- Research which is freely available for redistribution 